Laser Chem., Vol.16, pp. 245-253

Reprints available directly from the publisher

Photocopying permitted by license only
(C) 1996 OPA (Overseas Publishers Association) Amsterdam B.V. Published in The Netherlands by Harwood Academic Publishers GmbH

\title{
PHOTOLYSIS OF SIH BY THE THIRD HARMONIC OF A Nd:YAG LASER AT 355 NM
}

\author{
K. SENTRAYAN, E. HAQUE, A. MICHAEL and V. S. KUSHAWAHA \\ Laser Physics Laboratory, Department of Physics, Howard University, \\ Washington, D. C. 20059 U.S.A
}

(Received 15 October, 1995)

The photolysis of silane $\left(\mathrm{SiH}_{4}\right)$ was carried out using the third harmonic of a Nd: YAG laser at $355 \mathrm{~nm}$, at a fixed $\mathrm{SiH}_{4}$ pressure of $350 \mathrm{Torr}$, varying the laser energy fluence in the range of $30-300 \mathrm{Jcm}^{-2}$. The emission spectra indicates that the photofragments formed are $\mathrm{SiH}_{2}, \mathrm{SiH}, \mathrm{Si}, \mathrm{H}_{2}$, and $\mathrm{H}$. The $\left(\mathrm{A}^{1} \mathrm{~B}_{1}-\mathrm{X}^{1} \mathrm{~A}_{1}\right)$ transitions at $552.7 \mathrm{~nm}, 525.3 \mathrm{~nm}, 505.6 \mathrm{~nm}$, and $484.7 \mathrm{~nm}$ of $\mathrm{SiH}_{2}$ are due to a two photon absorption process. The $\left(\mathrm{A}^{2} \Delta-\mathrm{X}^{2} \pi\right)$ transitions of $\mathrm{SiH}$ at $425.9 \mathrm{~nm}, 418 \mathrm{~nm}, 414.2 \mathrm{~nm}, 412.8 \mathrm{~nm}$ and $395.6 \mathrm{~nm}$ are due to a three photon absorption process. The brownish white deposit on the cell windows indicates the presence of amorphous silicon (a:Si-H). The two atomic lines of $\operatorname{Si}\left(4 s^{1} P^{0} \rightarrow 3 p^{21} D_{2}\right)$ at $288.1 \mathrm{~nm}$, and $\left(4 s^{3} P_{j} \rightarrow 3 P^{3} P_{j}\right)$ at $251.6 \mathrm{~nm}$ are observed. The atomic Si transitions are due to a three photon absorption. We observed seven transitions due to molecular hydrogen at wavelengths $577.5 \mathrm{~nm}, 565.5 \mathrm{~nm}, 534.4 \mathrm{~nm}, 542.5 \mathrm{~nm}, 471 \mathrm{~nm}, 461.7 \mathrm{~nm}$, and 455.4 $\mathrm{nm}$. These bands are due to a four photon absorption process. In addition to the molecular bands we also observed hydrogen atomic lines $\mathrm{H}_{\beta}, \mathrm{H}_{\gamma}$ and $\mathrm{H}_{\delta}$.

\section{INTRODUCTION}

The photolysis of silane can be useful in developing growth models for thin films in microelectronics industry. ${ }^{1,2}$ The photochemical pathways of the silane dissociation process have had a long and controversial history and finally have been resolved in favour of a three-center elimination reaction to form silylene $\left(\mathrm{SiH}_{2}\right)$ and molecular hydrogen. ${ }^{3-6}$

The primary photodissociative mechanism of $\mathrm{SiH}_{4}$ in the formation of silylene may be described as follows:

$$
\begin{aligned}
& \mathrm{SiH}_{4} \rightarrow \mathrm{SiH}_{4}^{*} \\
& \mathrm{SiH}_{4} \rightarrow \mathrm{SiH}_{2}+\mathrm{H}_{2} \\
& \mathrm{SiH}_{4} \rightarrow \mathrm{SiH}_{2}+2 \mathrm{H}
\end{aligned}
$$

The other possible mechanism in the formation of atomic silicon and silyl radical may be described as follows:

$$
\begin{aligned}
& \mathrm{SiH}_{4} \rightarrow \mathrm{Si}+2 \mathrm{H}_{2} \\
& \mathrm{SiH}_{2} \rightarrow \mathrm{Si}+\mathrm{H}_{2} \\
& \mathrm{SiH}_{4} \rightarrow \mathrm{SiH}_{3}+\mathrm{H}
\end{aligned}
$$


The formation of SiH may be described as follows:

$$
\mathrm{SiH}_{4} \rightarrow \mathrm{SiH}+\mathrm{H}_{2}+\mathrm{H}
$$

Though the breaking of $\mathrm{Si}-\mathrm{H}$ bond requires about $2.5 \mathrm{eV}$ which corresponds to a single photon energy at $355 \mathrm{~nm}$, scission of that bond is not necessarily the step by which $\mathrm{SiH}_{4}$ dissociation is initiated. A detailed kinetic and spectroscopic study is necessary to establish a definite photochemical pathways.

The excimer laser induced fluorescence (LIF) emission from silylene has been reported in the photodissociation of silane. ${ }^{7}$ Spectroscopic investigation of the emission due to the transition of silylene $\left({ }^{1} B_{1}\right) \rightarrow\left({ }^{1} A_{1}\right)$ from the photodissociation of pure $\mathrm{SiH}_{4}$ and $\mathrm{SiH}_{4}: \mathrm{SiF}_{4}$ mixture, induced by the multiphoton absorption of an unfocused $\mathrm{CO}_{2}$ laser has been reported. ${ }^{8}$ It is interesting to note that the emission due to the photodissociation of $\mathrm{SiH}_{4}$ induced by a focused laser is different from that of an unfocused beam. For example, Deutsch ${ }^{9}$ observed the emission from the excited states of $\mathrm{H}, \mathrm{H}_{2}$, and $\mathrm{SiH}$ induced by a focused $\mathrm{CO}_{2}$ laser which is similar to that of a glow discharge ${ }^{10,11}$ but different from the emission observed by O'keefe et al. ${ }^{8}$ who used an unfocused $\mathrm{CO}_{2}$ laser.

In an attempt to provide further experimental information on the photodissociation of silane, we have focused the third harmonic of a Nd:YAG laser at $355 \mathrm{~nm}$, creating a small interaction zone of volume $\left(10^{-6} \mathrm{~cm}^{3}\right)$. The short pulse duration of the laser (8ns) eliminates the chain reactions. The emission due to various photofragments are collected by a Photomultiplier .Tube (PMT) and recorded by a multichannel analyzer (MCA) at a fixed silane pressure of 350 Torr and varying the intensity of the laser. The experimental method used and the results obtained will be discussed below.

\section{EXPERIMENTAL}

The experimental set-up used in the present investigation is shown in Figure 1. The silane used in this experiment was semiconductor grade, obtained from Air products. The sample cell was made up of stainless steel tubing of one inch internal diameter. A constricted tubing of $1 / 4^{\prime \prime}$ internal diameter, also made of stainless steel tubing was welded inside the main cell with clear access to $\mathrm{SiH}_{4}$ fillings and measuring the pressure in the constricted tubing. Both ends of the cell were attached with $1 / 4^{\prime \prime}$ thick quartz windows and Viton O-rings. The total length of the cell was $40 \mathrm{~cm}$. The cell was evacuated prior to filling the silane gas. The gas pressure was measured by a calibrated pressure gauge.

The photolysis was carried out using the third harmonic of a Nd:YAG laser at 355 $\mathrm{nm}$ (JKJ model HY-500). The laser was a multimode, linearly polarized with $8 \mathrm{~ns}$ pulse duration and $6.3 \mathrm{~cm}^{-1}$ line-width. The laser was operated at a repetition rate of $10 \mathrm{~Hz}$ throughout the experiment. The laser was focused at the center of the cell by a lens of focal length $34 \mathrm{~cm}$. The spot size of the focused beam was $100 \mu \mathrm{m}$. The output beam which consisted of the pump beam and emissions due to various photofragmented radicals was collimated by an another lens of focal length $50 \mathrm{~cm}$, dispersed by a McPherson model 270, 0.35 m monochrometer, detected by a Thron EMI Photomultiplier Tube(PMT) model No. 9635QB at room temperature and recorded by a 


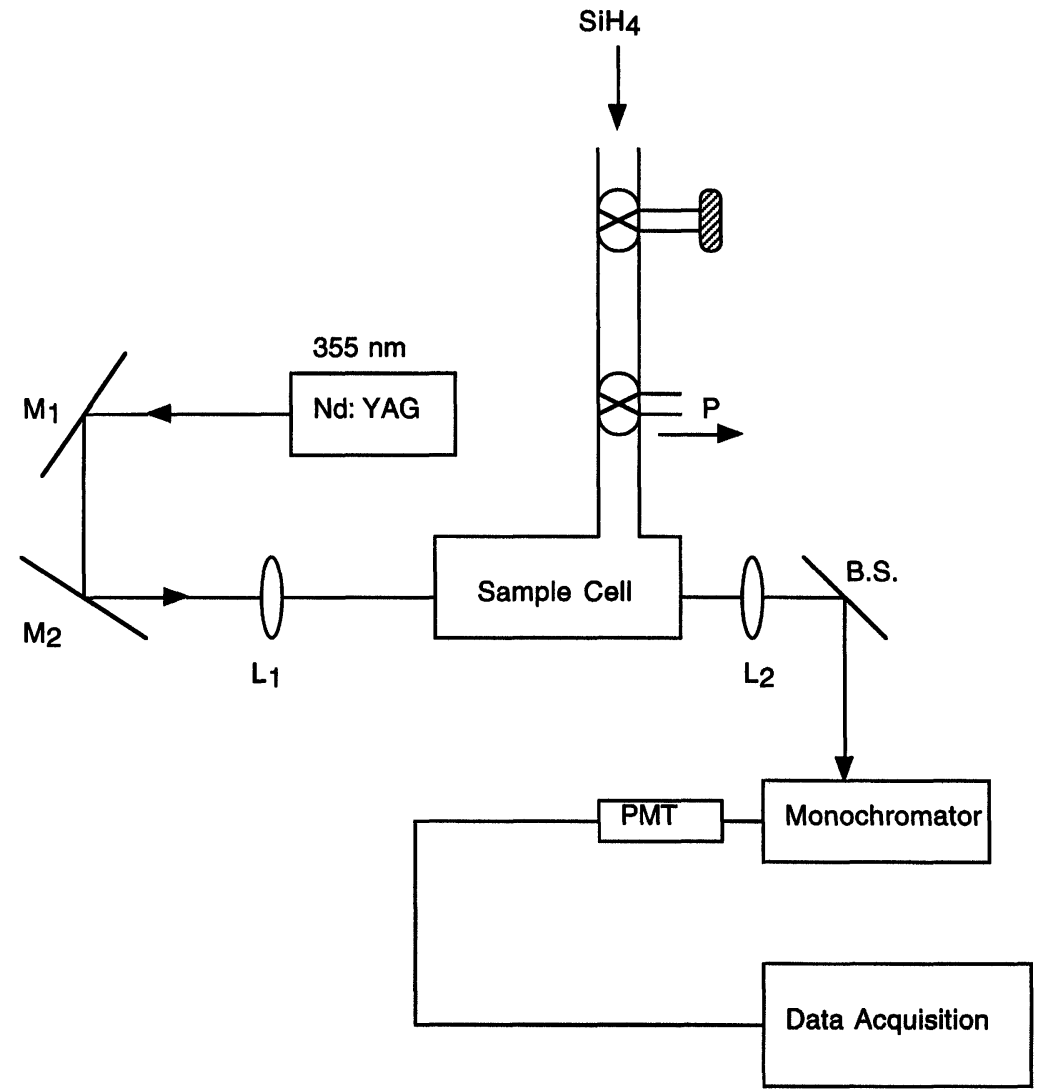

Figure 1 The experimental set-up used in the present study.

Norland 5600 multichannel analyzer (MCA) in the multichannel scalling (MCS) mode. Multichannel scalling is a time sweep of the channels in the MCA, with each channel being an interval of time equal to the total sweep time/ total channel swept. During each channel time interval (1s) in our case, the memory content for that channel is available for input data counting in the form of serial digital pulses. Thus, the resulting display is a frequency/wavelength histogram. In order to establish the possible photochemical pathway, at a fixed $\mathrm{SiH}_{4}$ pressure of 350 Torr we varied the energy fluence of the photolysing laser in the range of $30-300 \mathrm{Jcm}^{-2}$, by keeping the number of pulses fixed (10 pulses per second) and varying the average energy per pulse, we recorded the emission spectrum due to various photofragments. The results will be discussed as follows:

\section{RESULTS AND DISCUSSION}

Since our interest is to investigate whether the dissociation of $\mathrm{SiH}_{4}$ and the subsequent emission from the excited states of various fragments are due to multiphoton absorption, 
we varied the energy fluence of the laser in the range of $30-300 \mathrm{Jcm}^{-2}$. The emission spectra due to various excited states of the fragments such as $\mathrm{SiH}_{2}, \mathrm{SiH}, \mathrm{H}_{2}, \mathrm{H}$, and $\mathrm{Si}$ dissociated from $\mathrm{SiH}_{4}$ at three different energy fluences namely, $31 \mathrm{Jcm}^{-2}, 188 \mathrm{Jcm}^{-2}$, and $307 \mathrm{Jcm}^{-2}$, at a fixed $\mathrm{SiH}_{4}$ pressure of 350 Torr is shown in Figure 2.

The $\left(\mathrm{A}^{1} \mathrm{~B}_{1}-\mathrm{X}^{1} \mathrm{~A}_{1}\right)$ transition is a well known transition of $\mathrm{SiH}_{2}$ and often used to detect the $\mathrm{SiH}_{2}$ radical. ${ }^{12}$ The equilibrium bond angle of $\mathrm{H}-\mathrm{Si}-\mathrm{H}$ is $92^{\circ}$ for the ground state and $112^{\circ}$ for the excited state. Due to this large difference in the bond angle the $v_{2}$ progressions $\mathrm{A}\left(0, \mathrm{v}_{2}, 0\right)-\mathrm{X}(0,0,0)$ can clearly be observed; here, $\mathrm{v}_{2}=0-7$. The seven strongest transition are at the wavelengths: $643.6 \mathrm{~nm}, 609.8 \mathrm{~nm}, 579.7 \mathrm{~nm}, 552.7 \mathrm{~nm}$,

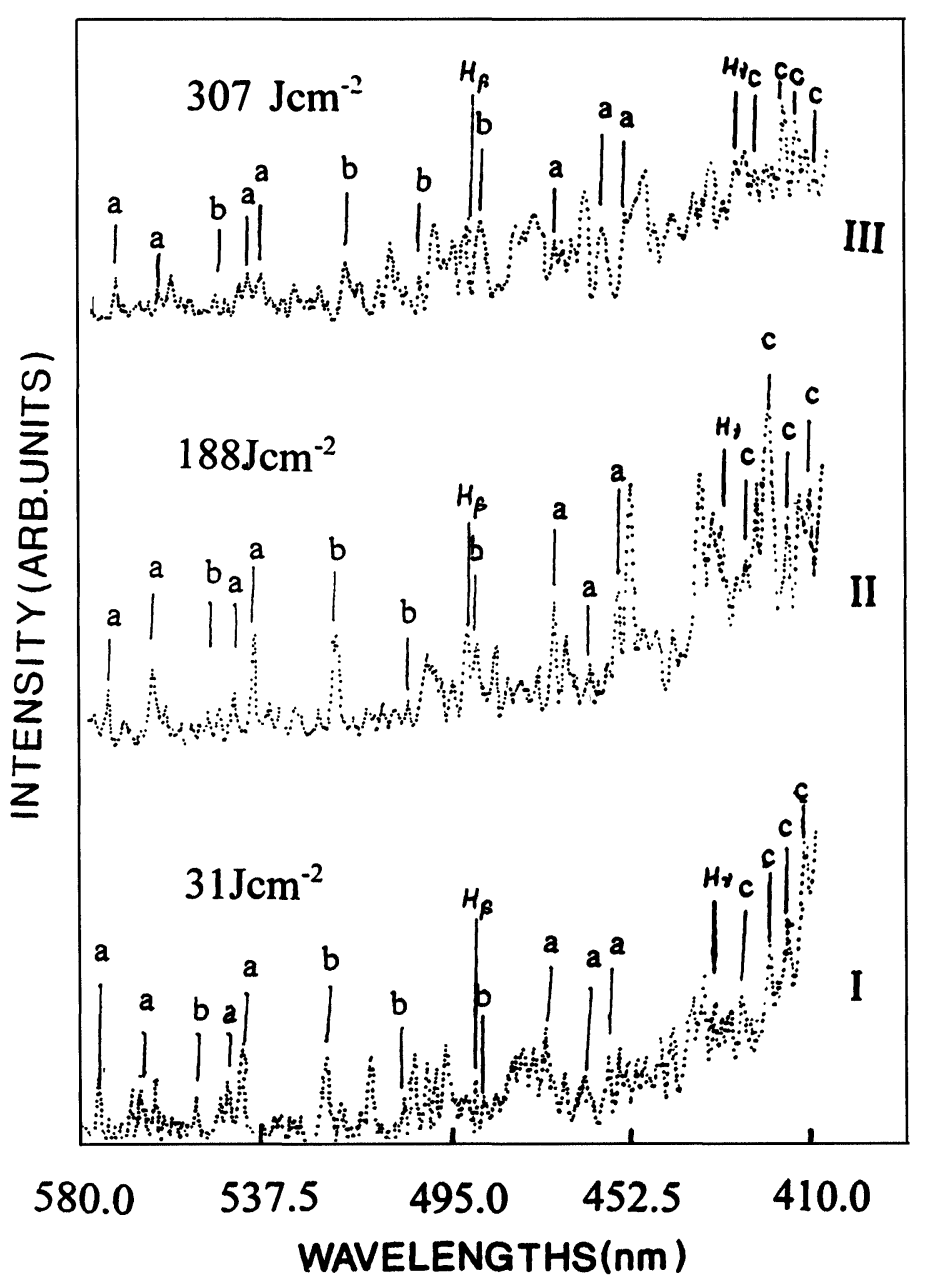

Figure 2A Emission spectra due to various excited states of the fragments such as $\mathrm{SiH}_{2}, \mathrm{SiH}, \mathrm{Si}, \mathrm{H}_{2}$, and $\mathrm{H}$ dissociated from $\mathrm{SiH}_{4}$ at three different energy fluences namely, $31 \mathrm{Jcm}^{-2}, 188 \mathrm{Jcm}^{-2}$ and $307 \mathrm{Jcm}^{-2}$ at a fixed $\mathrm{SiH}_{4}$ pressure of 350 Torr. The notations a, b, c, and d are molecular bands of hydrogen, $\mathrm{SiH}_{2}$ : $\left(\mathrm{A}^{1} \mathrm{~B}^{1}-\mathrm{X}^{1} \mathrm{~A}_{1}\right), \mathrm{SiH}:\left(\mathrm{A}^{2} \Delta-\mathrm{X}^{2} \pi\right), \mathrm{Si}$ atomic lines, respectively; $\mathrm{H}_{\beta}, \mathrm{H}_{\gamma}$, and $\mathrm{H}_{\delta}$ are atomic lines of hydrogen. The scanning range is $580 \mathrm{~nm}-410 \mathrm{~nm}$. 
$525.3 \mathrm{~nm}, 505.6 \mathrm{~nm}$, and $484.7 \mathrm{~nm}$. We observed four $\mathrm{SiH}_{2}$ transitions at wavelengths $552.7 \mathrm{~nm}, 525.3 \mathrm{~nm}, 505.6 \mathrm{~nm}$, and $484.7 \mathrm{~nm}$ within our scanning range that are indicated as "b" in Figure 2.

Based on the energy level diagram of $\mathrm{SiH}_{2}$ given (see Fig. 3.), $\mathrm{SiH}_{2}$ in the ${ }^{1} \mathrm{~B}_{1}$ state can be generated from $\mathrm{SiH}_{4}$ with excitation energy more than $4.6 \mathrm{eV}$. This clearly indicates that the $\left({ }^{1} B_{1}-{ }^{1} A_{1}\right)$ transitions are due to a two photon absorption. In order to establish a relationship between the emission intensity of (B-A) transitions and the laser energy fluence, we measured the relative intensity of (B-A) transitions at various laser energy fluences and the results are plotted in Figure 4. A nearly quadratic dependence of the emission intensity on the laser energy fluence for all (B-A) transitions was observed. This indicates that these transitions are due to a two photon absorption.

We have observed a band system shown as "c" in Figure 2 due to $\left(\mathrm{A}^{2} \Delta-\mathrm{X}^{2} \pi\right)$ transitions of $\mathrm{SiH}$ at $425.9 \mathrm{~nm}\left(\mathrm{v}^{\prime}=2, \mathrm{v}^{\prime \prime}=2\right), 418.3 \mathrm{~nm}\left(\mathrm{v}^{\prime}=1, \mathrm{v}^{\prime \prime}=1\right), 414.2 \mathrm{~nm}\left(\mathrm{v}^{\prime}=0\right.$, $\left.\mathrm{v}^{\prime \prime}=0\right), 412.8 \mathrm{~nm}\left(\mathrm{v}^{\prime}=0, \mathrm{v}^{\prime \prime}=2\right)$, and $395.6 \mathrm{~nm}\left(\mathrm{v}^{\prime}=2, \mathrm{v}^{\prime \prime}=1\right)$. These transitions are spectroscopically significant due to the presence of $\mathrm{SiH}$ in the stellar atmosphere. ${ }^{13,14}$ The threshold energy to produce $\mathrm{SiH}\left(\mathrm{A}^{2} \Delta\right)$ radical is in the range of $9.57-10.03 \mathrm{ev}^{15}$ which corresponds to three photons at $355 \mathrm{~nm}$. The experimentally measured emission intensity on the laser energy fluence plotted in Figure 5 confirms that these transitions are due to a three photon absorption process.

The observation of atomic lines of silicon and molecular bands of hydrogen is similar to that of Bosov et al. ${ }^{16}$ who showed that a cw $\mathrm{CO}_{2}$ laser dissociates $\mathrm{SiH}_{4}$ at a pressure of 200 Torr into silicon and hydrogen. The threshold energy for the formation of $\mathrm{Si} 4 \mathrm{~s}^{1} \mathrm{P}_{0}$ is in the range of $10.03-10.64 \mathrm{eV} .{ }^{15}$ This indicates that the $\mathrm{Si}$ atomic transitions are due to a three photon absorption process. Although the transition probability for the line at $288.1 \mathrm{~nm}$ and $251.6 \mathrm{~nm}$ are equal, ${ }^{17}$ we have observed that the intensity of the transition at $288.1 \mathrm{~nm}$ is nearly twice stronger than that at $251.6 \mathrm{~nm}$. Washida et al. ${ }^{15}$ observed that the intensity of the transition at $288.1 \mathrm{~nm}$

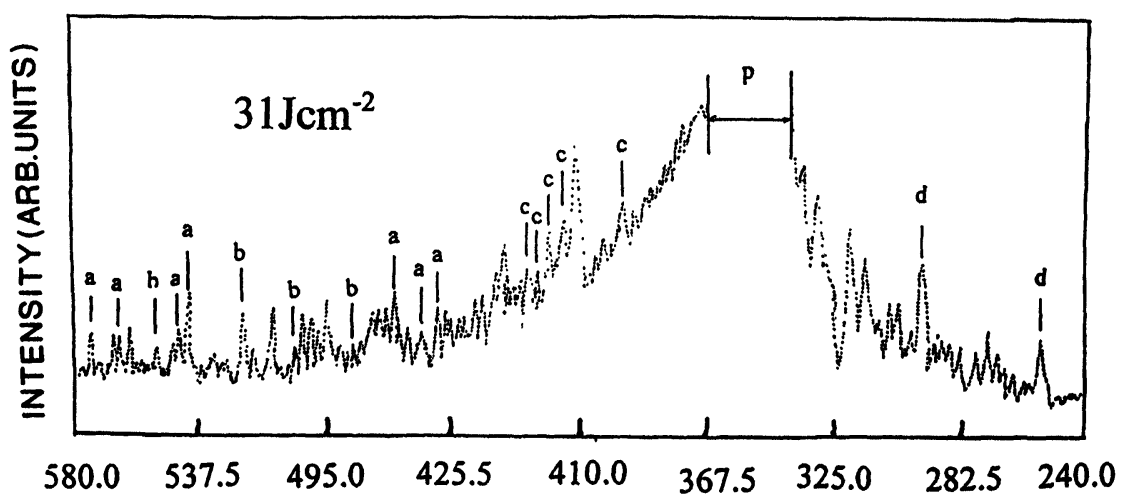

\section{WAVELENGTHS(nm)}

Figure 2B The same notations as in Figure 2A except the laser energy fluence is $31 \mathrm{Jcm}^{-2}$ and the scanning range is $580 \mathrm{~nm}-240 \mathrm{~nm}$. 


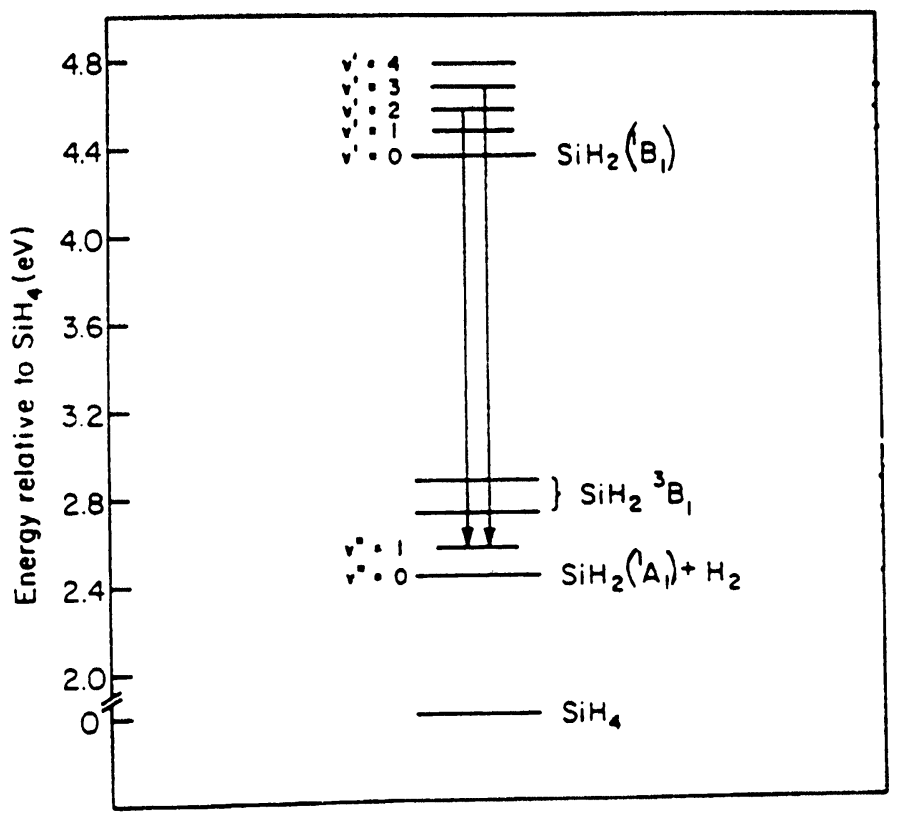

Energy-level diagram for $\mathrm{SiH}_{2}$.

Figure 3 The energy level diagam of $\mathrm{SiH}_{2}$.

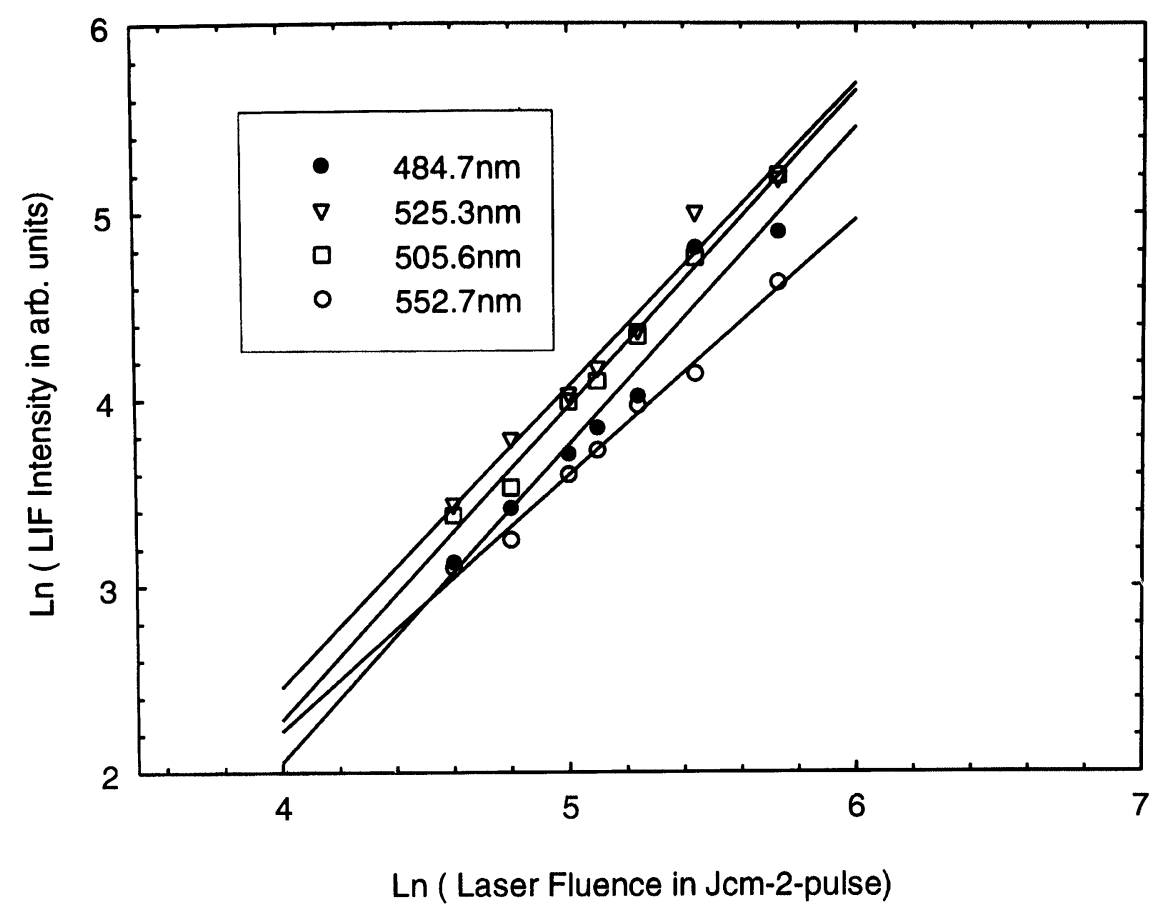

Figure 4 The relative intensity of $\left(\mathrm{A}^{1} \mathrm{~B}_{1}-\mathrm{X}^{1} \mathrm{~A}^{1}\right)$ transitions of $\mathrm{SiH}_{2}$ at a fixed $\mathrm{SiH}_{4}$ pressure of 350 Torr and at various laser energy fluences. The slope, varience, and maximum deviation for various transitions are, respectively given in paranthesis as: $484.7 \mathrm{~nm}(1.74,0.02$, and 0.311$) ; 525.3 \mathrm{~nm}(1.62,0.01$, and 0.216$) ; 505.6 \mathrm{~nm}$ $(1.68,0.05$, and 0.10$), 552.7 \mathrm{~nm}(1.38,0.03$, and 0.07$)$. 


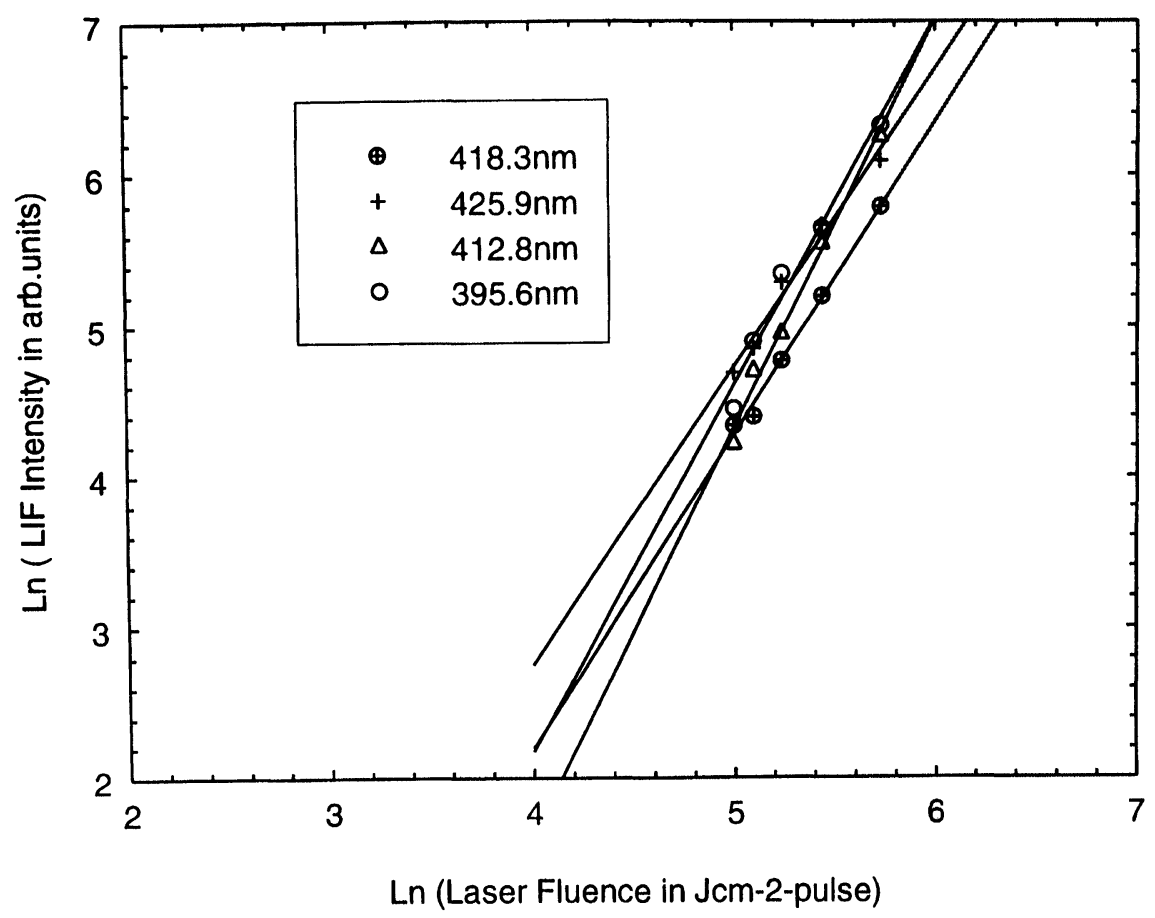

Figure 5 The relative intensity of $\left(\mathrm{A}^{2} \Delta-\mathrm{X}^{2} \pi\right)$ transitions of $\mathrm{SiH}$ at a fixed $\mathrm{SiH}_{4}$ pressure of $350 \mathrm{Torr}$ and at various laser energy fluences. The slope, varience, and maximum deviation for various transitions are, respectively given in paranthesis as: $418.3 \mathrm{~nm}(2.07,0.04$, and 0.1$) ; 425.9 \mathrm{~nm}(2.05,0.01$, and 0.1$) ; 412.8 \mathrm{~nm}$ $(2.54,0.04$, and 0.1$) ; 395.6 \mathrm{~nm}(2.80,0.01$, and 0.12$)$.

is three times stronger that at $251.6 \mathrm{~nm}$. This disagrees with electron impact experiment in which $251.6 \mathrm{~nm}$ is observed to be three times stronger than that at $288.1 \mathrm{~nm} .{ }^{18}$ The two atomic lines of $\mathrm{Si}$ at $288.1 \mathrm{~nm}$ and $251.6 \mathrm{~nm}$ observed in this study shown as "d" in Figure 2. We have observed seven transitions due to the molecular hydrogen wavelengths at $577.5 \mathrm{~nm}, 565.5 \mathrm{~nm}, 543.4 \mathrm{~nm}, 542.5 \mathrm{~nm}, 471 \mathrm{~nm}, 461.7 \mathrm{~nm}$, and $455.4 \mathrm{~nm}$ and are indicated as "a" in Figure 2. The upper electronic levels involved in the molecular hydrogen emission lies $100,000 \mathrm{~cm}^{-1}(13 \mathrm{eV})$ above the ground state, indicating that the molecular hydrogen bands are due to a four photon absorption. In addition to a molecular bands, we also observed atomic lines $\mathrm{H}_{\beta}(481.6 \mathrm{~nm}), \mathrm{H}_{\gamma}(434.0 \mathrm{~nm})$, and $\mathrm{H}_{\delta}$ (410. $2 \mathrm{~nm})$. The $\mathrm{H}_{\alpha}(656.3 \mathrm{~nm})$ was not observed due to the fact that our scanning range was only from $580.0 \mathrm{~nm}$ to $240.0 \mathrm{~nm}$.

Based on the appearance potentials and the processes for forming the ion fragments from $\mathrm{SiH}_{4}$ is given in Table $1{ }^{18,19}$ it is quite possible that the ionic radicals such as $\mathrm{SiH}_{4}^{+}$, $\mathrm{SiH}_{3}^{+}$, and $\mathrm{SiH}_{2}^{+}$may be formed due to four photon absorption. The dissociation energies of the successive bond ruptures in the positive ionic radicals of $\mathrm{SiH}_{4}$ given in the Table 2. ${ }^{18}$ The low dissociation energy value of the $\mathrm{SiH}_{3}^{+}-\mathrm{H}$ bond in $\mathrm{SiH}_{4}^{+}$indicates that $\mathrm{SiH}_{4}^{+}$may be primary source for the formation of $\mathrm{SiH}_{3}^{+}, \mathrm{SiH}_{2}^{+}, \mathrm{SiH}^{+}$and $\mathrm{Si}^{+}$. At a high pressure of 350 Torr, the recombination,, ionic collision process are fast (few ps); within 
Table 1 Appearence Potentials and Processes for the formation of the Fragments from $\mathrm{SiH}_{4}$.

\begin{tabular}{llc}
\hline Ions & \multicolumn{1}{c}{ Process } & Appearence Potential (eV) \\
\hline $\mathrm{SiH}_{4}^{+}$ & $\mathrm{SiH}_{4} \longrightarrow \mathrm{SiH}_{4}^{+}+\mathrm{e}$ & 11.4 \\
$\mathrm{SiH}_{3}^{+}$ & $\mathrm{SiH}_{4} \longrightarrow \mathrm{SiH}_{3}^{+}+\mathrm{H}+\mathrm{e}$ & $11.8 \pm 0.2$ \\
$\mathrm{SiH}_{2}^{+}$ & $\mathrm{SiH}_{4} \longrightarrow \mathrm{SiH}_{2}^{+}+\mathrm{H}_{2}+\mathrm{e}$ & $12.1 \pm 0.2$ \\
& $\mathrm{SiH}_{4} \longrightarrow \mathrm{SiH}_{2}^{+}+2 \mathrm{H}+\mathrm{e}$ & $16.5 \pm 0.3$ \\
$\mathrm{SiH}^{+}$ & $\mathrm{SiH}_{4} \longrightarrow \mathrm{SiH}^{+}+\mathrm{H}_{2}+\mathrm{H}+\mathrm{e}$ & $16.1 \pm 0.2$ \\
& $\mathrm{SiH}_{4} \longrightarrow \mathrm{SiH}^{+}+3 \mathrm{H}+\mathrm{e}$ & $20.4 \pm 0.5$ \\
$\mathrm{Si}^{+}$ & $\mathrm{SiH}_{4} \longrightarrow \mathrm{Si}^{+} 2 \mathrm{H}_{2}+\mathrm{e}$ & $11.7 \pm 0.2$ \\
& $\mathrm{SiH}_{4} \longrightarrow \mathrm{Si}^{+}+\mathrm{H}_{2}+2 \mathrm{H}+\mathrm{e}$ & $16.4 \pm 0.2$ \\
& $\mathrm{SiH}_{4} \longrightarrow \mathrm{Si}^{+}+4 \mathrm{H}+\mathrm{e}$ & $20.8 \pm 0.2$ \\
\hline
\end{tabular}

Table 2 Positive Ion Fragment Bond Dissociation Energies of $\mathrm{SiH}_{4}$.

\begin{tabular}{lc}
\hline Ion & Dissociation Energies $(\mathrm{eV})$ \\
\hline $\mathrm{SiH}_{3+}-\mathrm{H}$ & 0.4 \\
$\mathrm{SiH}_{2}^{+}-\mathrm{H}$ & 4.7 \\
$\mathrm{SiH}^{+}-\mathrm{H}$ & 3.9 \\
$\mathrm{Si}^{+}-\mathrm{H}$ & 0.4 \\
\hline
\end{tabular}

the time resolution of our detection system, we were unable to detect the any ionic fragments. It is evident from many broad peaks, the spectra displayed in Figure $2 a$ and $2 b$ are emission spectra of silane plasma. Many lines are neither resolved due to the limitation in the resolution of our detection system nor identified due to the fact that these transitions do not follow simple multiphoton processes but represent complex plasma interactions. The quantum mechanical calculation of the wave numbers of these transitions is very cumbersome and it is beyond the scope of this investigation.

We have observed brownish white deposit of a:Si-H on the cell windows due to decomposition of $\mathrm{SiH}_{4}$. Compared to unhydrogenated a:Si a:Si-H gives great improvements in the photo-conductivity and minority carrier life time ${ }^{20}$ and the utility to dope $\mathrm{n}$-and $\mathrm{p}$-type $\mathrm{e}^{21}$ thin films in microelectronics industry. In a: $\mathrm{Si}-\mathrm{H}$ formation, possible involvement of $\mathrm{SiH}_{2}$ (and/or $\mathrm{SiH}_{3}$ ) has been suggested by knights ${ }^{22}$ based on photolysis and electron impact dissociation studies by Lampe et al. ${ }^{23}$ Though our result support this hypothesis, one cannot ignore the role of ionic species for the formation of a: $\mathrm{Si}-\mathrm{H}$ due to plasma decomposition of $\mathrm{SiH}_{4}$.

\section{CONCLUSION}

The photolysis of silane has been carried out using the third harmonic of a Nd:YAG laser at $355 \mathrm{~nm}$. The photofragments identified in the present work are $\mathrm{SiH}_{2}, \mathrm{SiH}, \mathrm{Si}, \mathrm{H}_{2}$, and $\mathrm{H}$. The $\left(\mathrm{A}^{1} \mathrm{~B}_{1}-\mathrm{X}^{1} \mathrm{~A}_{1}\right)$ transitions of $\mathrm{SiH}_{2}$ and $\left(\mathrm{A}^{2} \Delta-\mathrm{X}^{2} \pi\right)$ transition of $\mathrm{SiH}$ are due to a two 
and three photon absorption respectively. The $\mathrm{Si}$ atomic lines are due to a three photon absorption process. The molecular bands of hydrogen are due to a four photon process. We observed the hydrogen atomic lines $\mathrm{H}_{\beta}, \mathrm{H}_{\gamma}$, and $\mathrm{H}_{\delta}$. We observed a brownish white deposition on the cell windows due to amorphous silicon (a:Si-H). The exact composition of $\mathrm{Si}$ and $\mathrm{H}$ are not known and mass spectrometric probing is necessary to establish the composition of $\mathrm{Si}$ and $\mathrm{H}$. The ionic radicals $\mathrm{SiH}_{2}^{+}, \mathrm{SiH}_{3}^{+}$, and $\mathrm{SiH}_{4}^{+}$are not detected in this investigation. The absence of these ions may be due to the fact that at a high silane pressure of 350 Torr, the recombination and ionic collision process are fast (few ps) in comparison with our time resolution of our detection system.

\section{Acknowledgements}

We gratefully acknowledge the financial support by the army research office (Grant No. DAAL 03-92-G-0136), NASA (Grant No. NAGW 2450), Wright Laboratory (Grant No. F33615-93-C-2365) and the collaborative core unit of Graduate school of Arts and Sciences of Howard University. We also thank Mr. E. Jones, Mr. Pinkey, and Mr. Ronald Tally for their technical help in the fabrication of the sample cell.

\section{References}

1. B. A. Scott, R. M. Plecenik and E. E. Simonyi, Appl. Phys. Lett., 3973 (1981).

2. M. E. Coltrin, R. J. Kee and J. A. Miller, J. Electrochem. Soc., 131425 (1984).

3. J. H. Purnell and R. Walsh, Proc. Roy. Soc., A293 543 (1966).

4. P. Neudorfl, A. Jodhan and O. P. Strauz, J. Phys. Chem., 84338 (1980).

5. B. A. Scott, R. M. Plecenik and E. E. Simonyi, Appl. Phys. Lett., 39425 (1981).

6. J. M. Jasinski and R. D. Estes, Chem. Phys. Letters, 117495 (1985).

7. P. J. Hargis, Tech. Digest Conf. Lasers and Electro Optics, Washington, D. C., June 10-12 48 (1981).

8. J. F. O'keefe and W. Lampe, Appl. Phys. Letters, 42219 (1983).

9. T. Deutsch, J. Chem. Phys., 701187 (1979).

10. R. W. Griffith, F. J. Kampas, P. E. Vanier, and M. D. Hirsch, J. Non Cryst. Solids, 35/36 195 (1980).

11. M. Taniguchi, M. Hirose, T. Hamasaki and Y. Osaka, Appl. Phys. Lett., 37787 (1980).

12. I. Dubois, Can, J. Phys., 462485 (1968).

13. H. D. Babcock, Astro. Phys. J., 102154 (1945).

14. A. J. Sauval, Sol. Phys., 10319 (1969).

15. W. Washida, Y. Matsumi, T. Hayashi, T. Ibuki, A. Hiraya and K. Shobatake, J. Chem. Phys., 832769 (1985).

16. N. G. Basov, E. P. Markin, A. N. Oraevskii, A. V. Pankratov and A. N. Skachkov, JETP Letters, 14165 (1971).

17. Goto, (Private Communication)

18. F. E. Saalfield and H. J. Svec, Inorg. Chem., 246 (1963).

19. J. D. Morrison and J. C. Traeger, Int. J. Mass Spectrom. Ion. Phys., 11289 (1973).

20. D. E. Carlson and C. Wrouski, Appl. Phys. Lett., 28671 (1976).

21. W. E. Spear and P. G. LeComber, Solid State Commn. 171193 (1975).

22. J. C. Knights, J. Non-Cryst. Solids, $35 / 36159$ (1980).

23. T. M. H. Cheng, T. Y. Yu, and F. W. Lampe, J. Phys. Chem., 781184 (1974).

24. R. M. More, (Ed), Laser interations with Atoms, Solids, and Plasmas. Plenum Press, New York, pp 325-355 (1992). 